\title{
Front Matter: Volume 7464
}

, "Front Matter: Volume 7464," Proc. SPIE 7464, Free-Space Laser Communications IX, 746401 (4 September 2009); doi: 10.1117/12.844703

EDIE Event: SPIE Optical Engineering + Applications, 2009, San Diego, California, SPIE. United States 


\title{
PROCEEDINGS OF SPIE
}

\section{Free-Space Laser Communications IX}

\author{
Arun K. Majumdar \\ Christopher C. Davis \\ Editors
}

2-3 August 2009

San Diego, California, United States

Sponsored and Published by

SPIE 
The papers included in this volume were part of the technical conference cited on the cover and title page. Papers were selected and subject to review by the editors and conference program committee. Some conference presentations may not be available for publication. The papers published in these proceedings reflect the work and thoughts of the authors and are published herein as submitted. The publisher is not responsible for the validity of the information or for any outcomes resulting from reliance thereon.

Please use the following format to cite material from this book:

Author(s), "Title of Paper," in Free-Space Laser Communications IX, edited by Arun K. Majumdar, Christopher C. Davis, Proceedings of SPIE Vol. 7464 (SPIE, Bellingham, WA, 2009) Article CID Number.

ISSN 0277-786X

ISBN 9780819477545

Published by

SPIE

P.O. Box 10, Bellingham, Washington 98227-0010 USA

Telephone +1 3606763290 (Pacific Time) · Fax +1 3606471445

SPIE.org

Copyright (C) 2009, Society of Photo-Optical Instrumentation Engineers

Copying of material in this book for internal or personal use, or for the internal or personal use of specific clients, beyond the fair use provisions granted by the U.S. Copyright Law is authorized by SPIE subject to payment of copying fees. The Transactional Reporting Service base fee for this volume is $\$ 18.00$ per article (or portion thereof), which should be paid directly to the Copyright Clearance Center (CCC), 222 Rosewood Drive, Danvers, MA 01923. Payment may also be made electronically through CCC Online at copyright.com. Other copying for republication, resale, advertising or promotion, or any form of systematic or multiple reproduction of any material in this book is prohibited except with permission in writing from the publisher. The CCC fee code is 0277-786X/09/\$18.00.

Printed in the United States of America.

Publication of record for individual papers is online in the SPIE Digital Library.



SPIEDigitalLibrary.org

Paper Numbering: Proceedings of SPIE follow an e-First publication model, with papers published first online and then in print and on CD-ROM. Papers are published as they are submitted and meet publication criteria. A unique, consistent, permanent citation identifier (CID) number is assigned to each article at the time of the first publication. Utilization of CIDs allows articles to be fully citable as soon they are published online, and connects the same identifier to all online, print, and electronic versions of the publication. SPIE uses a six-digit CID article numbering system in which:

- The first four digits correspond to the SPIE volume number.

- The last two digits indicate publication order within the volume using a Base 36 numbering system employing both numerals and letters. These two-number sets start with 00, 01, 02, 03, 04 , $05,06,07,08,09,0 A, 0 B \ldots$. OZ, followed by 10-1Z, 20-2Z, etc.

The CID number appears on each page of the manuscript. The complete citation is used on the first page, and an abbreviated version on subsequent pages. Numbers in the index correspond to the last two digits of the six-digit CID number. 


\section{Contents}

vii Conference Committee
ix Introduction

SESSION 1 FSO SYSTEM PERFORMANCE I

746402 An underwater optical wireless communication network (Invited Paper) [7464-01]

S. Arnon, Ben-Gurion Univ. of the Negev (Israel)

746403 Optical communications in atmospheric turbulence (Invited Paper) [7464-02]

L. B. Stotts, Defense Advanced Research Projects Agency (United States); B. Stadler, D. Hughes, Air Force Research Lab. (United States); P. Kolodzy, Kolodzy Consulting, LLC (United States); A. Pike, Defense Strategies and Systems, Inc. (United States); D. W. Young, J. Sluz, J. Juarez, The Johns Hopkins Univ. Applied Physics Lab. (United States); B. Graves, D. Dougherty, J. Douglass, AOptix Technologies, Inc. (United States); T. Martin, Science and Technology Associates (United States)

746404 Architecture overview and data summary of a $5.4 \mathrm{~km}$ free-space laser communication experiment [7464-03]

J. D. Moores, F. G. Walther, J. A. Greco, S. Michael, W. E. Wilcox, Jr., A. M. Volpicelli,

R. J. Magliocco, S. R. Henion, MIT Lincoln Lab. (United States)

746406 Adaptive optics and ESA's optical ground station [7464-05]

Z. Sodnik, J. Perdigues Armengol, European Space Agency, ESTEC (Netherlands);

R. H. Czichy, Synopta GmbH (Switzerland); R. Meyer, German Space Agency DLR

(Germany)

\section{SESSION 2 FSO SYSTEM PERFORMANCE II}

746407 Power spectra of a free space optical link in a maritime environment [7464-06]

R. Mahon, C. I. Moore, H. R. Burris, W. S. Rabinovich, M. R. Suite, L. M. Thomas, Naval Research Lab. (United States)

746408 Free-space optical data link to a small robot using modulating retroreflectors [7464-07] W. S. Rabinovich, J. L. Murphy, M. Suite, M. Ferraro, R. Mahon, P. Goetz, Naval Research Lab. (United States); K. Hacker, Naval Explosive Ordnance Disposal Technology Div. (United States); W. Freeman, SmartLogic, Inc. (United States); E. Saint Georges, S. Uecke, J. Sender, NovaSol (United States)

746409 Design of the high-speed framing, FEC, and interleaving hardware used in a $5.4 \mathrm{~km}$ free-space optical communication experiment [7464-08]

J. A. Greco, MIT Lincoln Lab. (United States) 
7464 OA Analysis of fog attenuation events at $850 \mathrm{~nm}$ measured on an $853 \mathbf{m}$ path [7464-09] V. Kvicera, M. Grabner, Czech Metrology Institute (Czech Republic); O. Fiser, Institute of Atmospheric Physics (Czech Republic)

SESSION $3 \quad$ INDOOR OPTICAL WIRELESS AND NON-LINE-OF-SIGHT FSO COMMUNICATION I

$7464 \mathrm{OB} \quad$ Indoor optical wireless communications: recent developments and future challenges

[7464-10]

D. O'Brien, Univ. of Oxford (United Kingdom)

7464 OC Indoor optical wireless communication: a GigaEthernet network prototype at $60 \mathrm{~dB}$ link margin [7464-11]

O. Bouchet, G. Launay, France Telecom (France); P. Besnard, FOTON-ENSSAT, CNRS (France)

7464 OD Indoor optical wireless communication by ultraviolet and visible light [7464-12]

K. Cui, G. Chen, Q. He, Z. Xu, Univ. of California, Riverside (United States)

$7464 \mathrm{OE} \quad$ Free-space optical data transmission using wavelength-division-multiplexing with a dedicated CMOS image sensor for indoor optical wireless LAN [7464-13]

K. Kagawa, J. Tanida, Osaka Univ. (Japan)

\section{SESSION 4 INDOOR OPTICAL WIRELESS AND NON-LINE-OF-SIGHT FSO COMMUNICATION II}

7464 OF Free space optical sensor network for fixed infrastructure sensing [7464-14] N. Agrawal, S. D. Milner, C. C. Davis, Univ. of Maryland, College Park (United States)

7464 OG Channel modeling for FSO communications and sensor networking inside structures [7464-15]

C. C. Davis, M. Eslami, N. Agrawal, Univ. of Maryland, College Park (United States)

$7464 \mathrm{OH} \quad$ Modulation and coding tradeoffs for non-line-of-sight ultraviolet communications [7464-16] Q. He, Univ. of California, Riverside (United States); B. M. Sadler, Army Research Lab. (United States); Z. Xu, Univ. of California, Riverside (United States)

$7464 \mathrm{Ol} \quad$ Non-line-of-sight ultraviolet communication channel characterization: modeling and validation [7464-17]

H. Ding, G. Chen, Univ. of California, Riverside (United States); A. K. Majumdar, Naval Air Warfare Ctr. (United States); B. M. Sadler, Army Research Lab. (United States); Z. Xu, Univ. of California, Riverside (United States)

\section{SESSION $5 \quad$ FADE MITIGATION, CODING, AND NETWORKING I}

$74640 \mathrm{~J}$ Optical communication through the turbulent atmosphere with transmitter and receiver diversity, wavefront control, and coherent detection [7464-18]

A. L. Puryear, V. W. S. Chan, Massachusetts Institute of Technology (United States)

7464 OK Chase combining for on-off-keying FSO communications [7464-20]

K. Kiasaleh, The Univ. of Texas at Dallas (United States) 
7464 OL Design of acousto-optic chaos based secure free-space optical communication links [7464-21]

A. K. Ghosh, P. Verma, S. Cheng, R. C. Huck, Univ. of Oklahoma (United States);

M. R. Chatterjee, M. Al-Saedi, Univ. of Dayton (United States)

7464 OM Efficient channel coding for multipulse pulse position modulation in terrestrial FSO systems [7464-22]

F. XU, M.-A. Khalighi, S. Bourennane, Institut Fresnel (France)

\section{SESSION 6 FADE MITIGATION, CODING, AND NETWORKING II}

7464 ON Performance of a FSO augmented RF mesh network [7464-23]

R. Peach, G. Burdge, J. Sonnenberg, M. Oyler, Harris Corp. (United States); D. Wayne, L. Andrews, R. Phillips, Univ. of Central Florida (United States)

746400 The use of statistical channel models, full-field propagation codes, and field data to predict link availability [7464-24]

S. Michael, R. R. Parenti, J. D. Moores, W. Wilcox, Jr., T. M. Yarnall, A. M. Volpicelli,

J. A. Taylor, MIT Lincoln Lab. (United States)

7464 OP A conical scan free space optical tracking system for fading channels [7464-25]

R. J. Murphy, A. M. Volpicelli, W. Wilcox, Jr., D. A. Crucioli, T. H. Williams, MIT Lincoln Lab. (United States)

$7464 \mathrm{OQ}$ A novel spatial tracking for FSO communications through turbulent atmosphere [7464-26]

K. Kiasaleh, The Univ. of Texas at Dallas (United States)

7464 OR Effects of atmospheric compensation techniques on the performance of synchronous receivers [7464-27]

A. Belmonte, Technical Univ. of Catalonia (Spain); J. M. Kahn, Stanford Univ. (United States)

SESSION 7 OPTICAL TURBULENCE CHARACTERIZATION AND LINK MODELING: JOINT SESSION WITH CONFERENCE 7463

7464 OS Level crossings and turbulence in free-space laser communications [7464-28]

H. J. Catrakis, A. J. Wachtor, J. Shockro, A. P. Freeman, R. C. Sokolowski, Univ. of California, Irvine (United States)

7464 OT Wave optics simulation of partially coherent and partially polarized beam propagation in turbulence [7464-30]

X. Xiao, D. Voelz, New Mexico State Univ. (United States)

$7464 \mathrm{OU}$ Modeling channel interference in an orbital angular momentum-multiplexed laser link [7464-31]

J. A. Anguita, Univ. of the Andes (Chile); M. A. Neifeld, The Univ. of Arizona (United States) and College of Optical Sciences, The Univ. of Arizona (United States); B. V. Vasic, The Univ. of Arizona (United States) 
$74640 \mathrm{~V} \quad$ A process for free-space laser communications system design [7464-32]

F. G. Walther, J. D. Moores, R. J. Murphy, S. Michael, G. A. Nowak, MIT Lincoln Lab. (United States)

7464 OW A free-space optical terminal for fading channels [7464-33]

T. Williams, R. J. Murphy, F. Walther, A. Volpicelli, B. Wilcox, D. Crucioli, MIT Lincoln Lab.

(United States)

7464 OX Measurement of beam wander using cone modulation in an optical free-space retro-reflective link [7464-34]

E. Saint Georges, S. Uecke, NovaSol (United States)

7464 OY Evaluation of a cone tracking algorithm for free-space optical communication in direct mode [7464-35]

E. Saint Georges, NovaSol (United States)

POSTER SESSION

746410 Optical birefringent $90^{\circ}$ hybrid for coherent receiver in free-space optical communication system [7464-37]

Y. Zhi, Y. Zhou, J. Sun, A. Yan, Z. Luan, L. Wang, L. Liu, Shanghai Institute of Optics and Fine Mechanics (China)

Author Index 


\title{
Conference Committee
}

\author{
Conference Chairs
}

Arun K. Majumdar, Naval Air Warfare Center (United States)

Christopher C. Davis, University of Maryland, College Park (United States)

Program Track Chairs

Stephen M. Hammel, Space and Naval Warfare Systems Center, San Diego (United States)

Alexander M. J. van Eijk, TNO Defense, Security and Safety (Netherlands)

Program Committee

Larry C. Andrews, University of Central Florida (United States)

Shlomi Arnon, Ben-Gurion University of the Negev (Israel)

Mikhail S. Belen'kii, Trex Enterprises Corporation (United States)

Don M. Boroson, MIT Lincoln Laboratory (United States)

Naresh Chand, BAE Systems (United States)

Frank D. Eaton, Air Force Research Laboratory (United States)

Bernhard Epple, DLR Standort Oberpfaffenhofen (Germany)

G. Charmaine Gilbreath, Naval Research Laboratory (United States)

Hennes Henniger, DLR Standort Oberpfaffenhofen (Germany)

Anton Kohnle, Forschungsgesellschaft für Angewandte

Naturwissenschaften e.V. (Germany)

Stuart D. Milner, University of Maryland, College Park (United States)

Michela Muñoz Fernández, Jet Propulsion Laboratory (United States)

Dominic C. O'Brien, University of Oxford (United Kingdom)

Jacobus M. Oschmann, Jr., Ball Corporation (United States)

Narasimha S. Prasad, NASA Langley Research Center (United States)

William S. Rabinovich, Naval Research Laboratory (United States)

Marcos Reyes Garcia-Talavera, Instituto de Astrofísica de Canarias (Spain)

Jennifer C. Ricklin, Defense Advanced Research Projects Agency (United States)

Thomas M. Shay, Air Force Research Laboratory (United States)

Larry B. Stotts, Defense Advanced Research Projects Agency (United States) 
Session Chairs

1 FSO System Performance I

Christopher C. Davis, University of Maryland, College Park (United States)

2 FSO System Performance II

Arun K. Majumdar, Naval Air Warfare Center (United States)

3 Indoor Optical Wireless and Non-Line-of-Sight FSO Communication I

Zhengyuan Xu, University of California, Riverside (United States)

Geoffrey L. Burdge, Harris Corporation (United States)

4 Indoor Optical Wireless and Non-Line-of-Sight FSO Communication II

Dominic C. O'Brien, University of Oxford (United Kingdom)

$5 \quad$ Fade Mitigation, Coding, and Networking I

Stuart D. Milner, University of Maryland, College Park (United States)

6 Fade Mitigation, Coding, and Networking II

Shlomi Arnon, Ben-Gurion University of the Negev (Israel)

Michele R. Suite, Naval Research Laboratory (United States)

7 Optical Turbulence Characterization and Link Modeling: Joint Session with Conference 7463

Alexander M. J. van Eijk, TNO Defence, Security and Safety

(Netherlands)

Christopher C. Davis, University of Maryland, College Park (United

States)

8 Components and System Design and Analysis

Rita Mahon, Naval Research Laboratory (United States)

William S. Rabinovich, Naval Research Laboratory (United States) 


\title{
Introduction
}

This volume contains the papers submitted and accepted as full manuscripts following presentation at the Free-Space Laser Communications IX conference. Free space optical (FSO) communication is now a mature field, but many exciting fundamental and technological challenges remain to improve its performance in a range of scenarios. Short range FSO systems are widely deployed and are available commercially. The performance of communication networks containing such links in addition to directional and omnidirectional RF connections continues however, to present research challenges. Military applications of FSO technology involving long range links, with mobile and airborne platforms, remains an area of active research and development. Very long range terrestrial links through the atmosphere can experience severe scintillation caused by atmospheric turbulence, which presents significant challenges in beam pointing and leads to deep fades. Clock synchronization is difficult to maintain in the face of these disturbances. An emerging area of interest involves underwater sensor networks that are connected by relatively short-range laser links. Some questions remain regarding how much the performance of FSO links through atmospheric turbulence can be improved with adaptive optics, and how these improvements depend on the length of the link. The performance of free space links can also be improved by forward error correction, interleaving, and packet-level correction codes. Clever transceiver implementations, new beam profiles, and the right modulation schemes can also improve link performance. Non-line-of-sight links using solar blind UV radiation scattered from transmitter to receiver open interesting communication scenarios. All these issues are addressed in papers published in this volume. Ground to satellite, satellite-to-satellite, and deep space optical communications present their own challenges, which are also discussed. The use of FSO communications in indoor spaces for secure communications and sensor networking over short ranges is attracting attention as a non-interfering alternative to RF communications, and several papers address this important area of research and development, including the channel modeling of interior spaces with diffuse reflections. At a fundamental level, several papers address measurement of the effects of the atmosphere on propagating beam waves, where atmospheric properties can be measured, and correlated with theoretical models describing phenomena such as obscuration, beam wander, scintillation and image motion.

\author{
Arun K. Majumdar \\ Christopher C. Davis
}


Downloaded From: https://www.spiedigitallibrary.org/conference-proceedings-of-spie on 25 Apr 2023

Terms of Use: https://www.spiedigitallibrary.org/terms-of-use 